\title{
Growth regulators and essential oil production
}

\author{
Cláudia L. Prins ${ }^{1 *}$, Ivo J. C. Vieiraª and Silvério P. Freitas ${ }^{1}$ \\ ${ }^{1}$ Setor de Plantas Daninhas e Medicinais, Laboratório de Fitotecnia, Centro de Ciências e Tecnologias Agropecuárias, \\ Universidade Estadual do Norte Fluminense Darcy Ribeiro, Av. Alberto Lamego 2000, 28013-602, Campos dos \\ Goytacazes - RJ, Brazil. \\ ${ }^{2}$ Setor de Química de Produtos Naturais, Laboratório de Ciências Químicas, Centro de Ciências e Tecnologia, \\ Universidade Estadual do Norte Fluminense Darcy Ribeiro.
}

* Corresponding author: prins@uenf.br; Tel/Fax. +55 2227397098.

Received: 30 May 2010; Accepted: 27 July 2010.

\section{ABSTRACT}

The aroma and fragrance industry is a billion-dollar world market which grows annually. Essential oils comprise the majority of compounds used by these industries. These sets of metabolites are formed mainly by monoterpenes, which are products of the plants' secondary metabolism. Biosynthesized from mevalonate and methylerythitol phosphate, the essential oil production depends not only on genetic factors and the developmental stage of plants, but also on environmental factors which could result in biochemical and physiological alterations in plants modifying the quantity and quality of the essential oil. These modifications impair aromatic plant production aimed at essential oil by reducing their quality. It is desirable to develop techniques of agronomical management to improve essential oil products and their specific compounds. Among other factors influencing essential oil production are plant growth regulators or plant hormones. Endogenous levels as well exogenous application could affect essential oil production and chemical composition. In this review we will present research in which plant growth regulators or their synthetic analogs were used and their effects on essential oil production.

Key words: auxins, cytokinins, gibberellins, ethylene, jasmonate, terpenoids

\section{INTRODUCTION}

The aroma and fragrance industries represent a market of $\$ 18$ billion annually and the international trade of essential oil presents an average rise of $10 \%$ a year. A great part of compounds used as fragrance and flavor are chemically synthesized from petroleum derivatives. The use of hard metals in the catalysis processes, however, becomes desirable a natural source of them (Schwab et al. 2008).

Essential oils are the most important raw materials of the fragrance and aroma industry. They are also used in the food and pharmaceutical industries due to their therapeutic, antimicrobial and antioxidant activities. Nevertheless, they have biological activities that make them able to be used as herbicides, pesticides and anticancer compounds (Mahmoud and Croteau 2002; Abrahim et al. 2003; Burfield and Reekie 2005; El Tamer 2005).

The essential oils are related to plant defense and pollinator attraction among other ecological functions. As other secondary metabolites groups, these compounds play an important role in the plant's fitness under environmental variation. For this reason, a common problem that occurs in aromatic plants cultivation is the quantitative and qualitative variation in response to the environment (Taiz and Zeiger 2004).

To supply market demands and industries requirements it is necessary to maintain a constant essential oil production and quality, mainly in terms of chemical composition (Silva 2002).

The essential oil production does not depend only on plant genetics or developmental stage. The environment and 
its changes can influence in a significant way biochemical pathways and physiological processes that alter plant metabolism and, therefore, the essential oil biosynthesis (Sangwan et al. 2001).

Since 1940 natural and synthetic growth regulators (GR) have been used in agriculture to control developmental processes like germination, vegetative growth, reproduction, maturation, senescence and post harvest (Basra 2000).

Although the use of GR in agriculture has been a usual practice for decades, little is known about the effects of these compounds on secondary metabolite production (Poyh and Ono 2006).

This review will focus on the effects of exogenous application of growth regulators on essential oil production of various species and the factors responsible for them.

Essential oils: Among the diversity of secondary metabolite classes we found the isoprenoids (also terpenes or terpenoids), whose name is related to its five-carbon structure: isopentenyl diphosphate (IPP). Isoprenoids occur in plants as primary metabolites (ubiquinone, plastoquinones, gibberellins, brassinosteroids, carotenoids and others) (Rodriguez-Concepción and Boronato 2002). However, isoprenoids classified as secondary metabolites are very important due to their ecological functions like attraction of pollinators and seed dispersion, protection against herbivores and allelophaty (Paré and Tumlinson 1999; Wink 2003).

Terpenes (the usual name) are biosynthesized through two pathways: mevalonate and methylerythritol phosphate (Figure 1). The first is located in the cytosol and endoplasmatic reticulum (Hadacek 2002), which has acetyl-CoA as its precursor, while the second occurs in the plastids from glyceraldehyde-3-phosphate and pyruvate (Rodriguez-Concepción and Boronato 2002). Both generate isopentenyl diphosphate (IPP), which is isomerized (isopentenyl diphosphate isomerase) forming dimethylallyl diphosphate (DMAPP), the isoprene synthase substrate, an enzyme that is present in the chloroplast responsible for the diphosphate break and isoprene (a five-carbon compound) formation. Adding an IPP molecule to DMAPP through prenyltransferases will generate geranyl diphosphate (GPP), a monoterpene $\left(C_{10}\right)$ precursor. Consecutive condensation of IPP (by special prenyltransferases) produces farnesyl diphosphate (FPP) and geranylgeranyl diphosphate (GGDP), which are precursors of sesquiterpenes $\left(\mathrm{C}_{15}\right)$ and diterpenes $\left(C_{20}\right)$, respectively (Figure 2). These terpene groups will be converted by terpene synthases giving rise to other compounds. There are also triterpenes, tetraterpenes and politerpenes, with 30, 40 and more than 45 carbons, respectively (Bohlmann et al. 1998; Trapp and Croteau 2001; Bohlmann and Keeling 2008). 


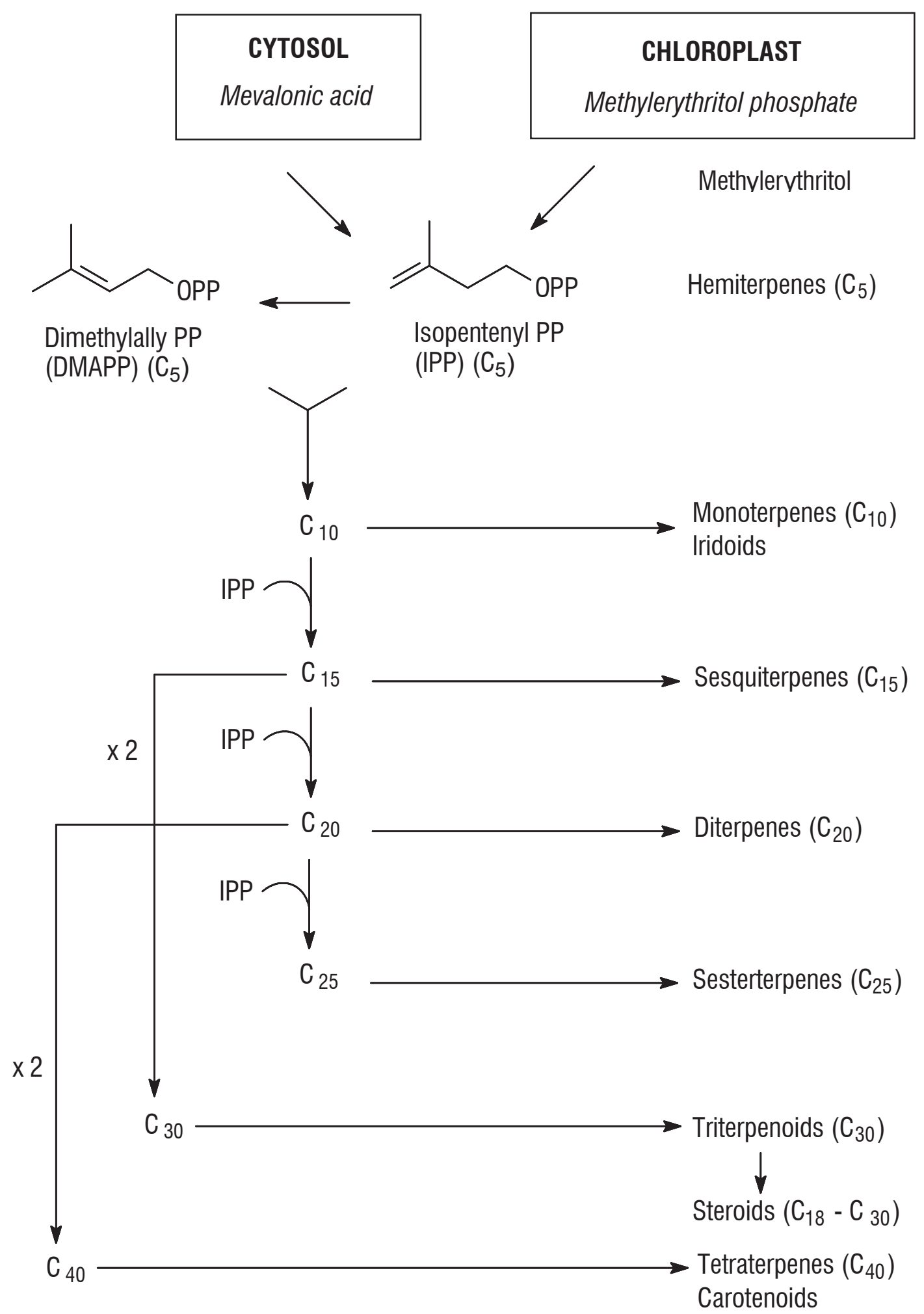

Figure 1. Simplified scheme of mevalonate and methylerythritol phosphate pathways for terpenoids biosynthesis (reproduced from Dewick, 2009). 
<smiles></smiles>

IPP<smiles>CC(C)=CCCC(C)C</smiles>

GPP<smiles>CC(C)=CC[Po+]</smiles>

DMAPP<smiles>CC(C)=CCCC(C)=CCCC(C)=CCc1ccccc1</smiles>

FPP<smiles>CC(O)(CO)C(O)CO</smiles>

MEP<smiles>CC1=CCCC2=C1CCC1=C2CCC(C)=C1COc1ccccc1</smiles>

GGPP

Figure 2. Terpenoids precursors (IPP and DMAPP). Methylerythritol phosphate from chloroplast pathway and main precursors of terpenoids groups: geranyl diphosphate (GPP), farnesyl diphosphate (FPP) and geranyl geranyl diphosphate (GGPP)

Terpene synthases products may suffer many reactions (oxidation, reduction, isomerization, conjugation, etc) giving rise to stereochemicals and metabolic variants (Kesselmeier and Staudt 1999; Sangwan et al. 2001), which deliver a range of chemical diversity found in this secondary metabolite class.

The production and accumulation of essencial oils are related to specialized structures since they are very toxic to cells. There are numerous sorts of specialized secretory structures like, for instance, glandular thricomes, secretory cavities, idioblasts and others (Gershenzon 1994). According to Gottlieb and Salatino (1987) the essential oil production and the secretory structure formation are closely connected.

Endogenous factors like development stage of whole plant and specific organs, and exogenous factors (biotic and abiotic) can alter essential oil production (Sangwan et al. 2001; Lima et al. 2003; Gobbo-Neto and Lopes 2007).

In a comprehensive review about essential oil production regulation Sangwan et al. (2001) indicated ontogeny, photosynthetic rate, photoperiod, light quality, climatic and seasonal changes, nutrition, humidity, salinity, temperature, storage structures and growth regulators as factors that alter quantitatively and qualitatively the production of this class of compounds.

According to Faroogi and Shukla (1999) growth regulators, or plant hormones, stimulate plant growth and terpene biosynthesis in a broad number of aromatic plant species, which result in beneficial changes in terpene quality and quantity.

The use of growth regulators in agricultural production has increased due to their positive influence on product quality. This is a common practice in small countries where this technology is necessary to achieve higher yields and better products (Poyo and Ono 2006).

It is known that plant growth and development are regulated by action and balance of different groups of growth regulators, which promote or inhibit such processes. Nevertheless, the effects of the use of plant growth regulators on essential oil production are not well known (Ortuño et al. 1999; Poyo and Ono 2006).

Plant Growth Regulators - Phytohormones: Plant growth regulator is a term which includes hormonal substances of natural occurrence (phytohormones) as well their synthetic analogues (Basra 2000). 
The concept of phytohormone was proposed by Julian von Sachs at the end of $19^{\text {th }}$ Century, who characterized them as mobile endogenous compounds acting as organ formers (Spartz and Gray 2008). Phytohormones are simple molecules that have specific effects on plant growth and are active at low concentrations (Nambara and Marion-Poll 2005; Teale et al. 2006).

All the aspects of plant growth and development are under phytohormone control. A single phytohormone can regulate a wide range of processes. On the other hand, a unique process can be regulated by the action of many plant hormones. Although nowadays the use of mutants is a valuable tool to clarify hormone functions, traditionally the physiological effects of diverse plant hormones has been established by their exogenous application (Gray 2004).

Five classes of phytohormones are classic (Figure 3): auxins (1), cytokinins (2), gibberellins (3), abscisic acid (4) and ethylene (Nambara e Marion-Poll, 2005). In addition, compounds like jasmonate (5) and brassinosteroids (6) are also classified as plant hormones (Taiz and Zeiger 2004).<smiles>O=C(O)Cc1c[nH]c2ccccc12</smiles>

1<smiles>CC1=CC(=O)CC(C)(C)C1(O)/C=C/C(C)=C/C(=O)O</smiles><smiles>[R]Nc1ncnc2[nH]cnc12</smiles>

2

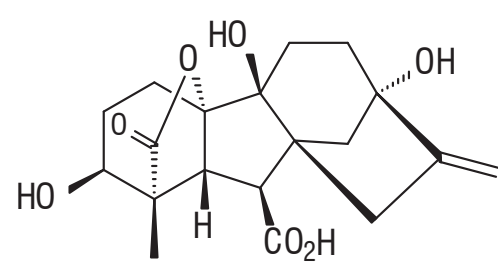

3<smiles>CC/C=C/C[C@H]1C(=O)CCC1CC(C)=O</smiles>

5<smiles>CC(C)C(C)[C@H](O)[C@H](O)[C@@H](C)C1CCC2C3COC(=O)C4C[C@@H](O)[C@@H](O)CC4C3CCC21</smiles>

Figure 3. Main phytohormones groups structures.

Auxins (AUX) act from the embryo formation until tropic stimulus processes, but are known as growth hormone due to their role in cell elongation. The response to auxin includes regulation of a broad number of genes. In plants the predominant auxin is indol acetic acid (IAA). There is a large biosynthesis of auxin in young tissues on the shoot as well in the root meristematic apices. Auxin is distinguished from the other hormones by its specific and active transport, which is one of the factors that influence the activity of this hormone (Pozo et al. 2005; Teale et al. 2006; Spartz and Gray 2008).

Cytokinin (CYT) is a phytohormone that participates in events in the course of whole plant ontogeny, from fecundated ovule to senescence and death. It is present in processes such as cell division, shoot initiation and growth, senescence delay and photomorfogenic development, control of chloroplast division and growth, modulation of metabolism and morphogenesis in response to environmental stimulus (Chenyad 'ev 2000; Kieber 2002; Pozo et al. 2005; Hirose et al. 2007).

Gibberellins (GA) are regulators of plant height. They are diterpenes which regulate stem elongation, seed germination and flowering. They are also associated with juvenile to adult transition processes, promote fructification and play an important role on seed germination by activation of embryo vegetative growth and mobilization of energetic reserves from endosperm (Taiz and Zeiger 2004; Spartz and Gray 2008). 
Abscisic acid (ABA) has great importance in developmental processes and seed germination, as the induction of seed dormancy, protein and lipid synthesis, tolerance to desiccation and inhibition of the embryonic to vegetative development. In mature plants $A B A$ acts on the response to drought through stomata aperture. It also acts on adaptation to stress conditions like low temperature, salinity, hypoxia and in response to pathogen attacks. In a general way $A B A$ is considered a hormone with inhibitory activity on growth (Nambara and Marion-Poll 2005; Pozo et al. 2005).

Ethylene (ET) is a phytohormone that acts on seed germination, shoot and root growth, flower development, flower and leaf senescence and abscission and fruit maturation. Its particularity is the emission by diffusion as a gas. It is also associated with plant defense, acting on the induction of xylem inclusions and phytoalexins synthesis. Ethylene production can be induced by factors like drought, inundation, ozone exposure, or mechanical injury, which associate it with stress responses (Taiz and Zeiger 2004; Adie et al. 2007).

Among the other phytohormones, jasmonate $(\mathrm{JA})$ is distinguished by its association with processes of response to herbivore and pathogen attacks through chemical defense inductions like phytoalexin biosynthesis. Furthermore, jasmonate regulates a variety of responses to abiotic stress, as well as processes associated with reproduction and senescence. The physiological effects are not restricted to jasmonic acid, but to a broad range of compounds including precursors and conjugated which acts as signaling molecules on plant development and adaptation to stress conditions (Schaller and others 2005; Wasternack 2007; Spartz and Gray 2008).

Brassinosteroid (BR) is a phytohormone that acts regulating cell elongation and division. It affects plant curvature, reproductive and vascular development, membrane polarization and proton pumping, the source-sink relationship, and stress modulation through interaction with environmental signs. Brassinosteroid levels vary among tissues, but the mainly sources are grains of pollen and immature seeds. Normally immature tissues have a higher brassinosteroid concentration, which explains its effect on young tissues. Mutant plants to brassinosteroids are dwarf and have a growth pattern similar to plants exposed to light even when it is absent. These mutants show altered leaf morphology when exposed to light (Clousse and Sasse 1998).

\section{Essential oil production using plant growth regulators:} The effects of growth regulators (Figure 4) on essential oil production, by means of leaf spraying or in vitro culture systems, are very variable. Changes only on yield or content of essential oil could be verified. In some cases chemical changes also occur, in others no effect is noticed. If taken into account that growth regulators influence plant growth and development, affecting physiological and biochemical processes, or even gene regulation, there are a great number of ways in which applications of those compounds could alter the essential oil production (Shukla and Faroogi 1990).

One of the manners of influencing essential oil production is through effects upon plant growth. The induction of leaf and flower production or a general increase in biomass can result in higher essential oil yield. In mint (Mentha arvensis) the use of $200 \mathrm{ppm}$ of cinetine (7) resulted in an increase of biomass production which, according to Faroogi and others (2003), contributed to a rise in essential oil yield. In another assay with $M$. arvensis L. var. piperascens Mal., Farooqi and Sharma (1988) verified that a decrease in plant size associated with a higher leaf production was the cause of the increment in essential oil yield in plants treated with cytokinins and naphthalene acetic acid (NAA) (8).

Essential oils occur throughout the plant, but they are frequently found in flowers and leaves. Poyh and Ono (2006) observed in sage (Salvia officinalis) treated with $100 \mathrm{mg} \mathrm{L}^{-1}$ of gibberellic acid (GA) higher essential oil content compared to control plants. According to the authors, this was a result of an increase in leaf number. Application of ethrel [(2-chloroethyl) phosphonic acid] (9), which is degraded when in contact with plant cells producing ethylene, in concentrations of 50 and $100 \mathrm{mg} \mathrm{L}^{-1}$, resulted in a decrease in plant height, yet there was an increase of $38-42 \%$ on fresh and dry mass of flowers in relation to control plants. On the other hand, high concentrations (250 and $500 \mathrm{mg} \mathrm{L}^{-1}$ ) had negative effects not only on plant height, but also on flower production. Nevertheless, single flower mass was not influenced (Haque and others 2007). Applications of different forms of brassinosteroid analogues (ketonic and lactonic spirostane) resulted in an increase of fresh matter of leaves and higher menthol production in Mentha arvensis L. (Maia et al. 2004). 
Due to its high toxicity essential oils are biosynthesized and stored in specialized structures (Gershenzon 1994). Thus the occurrence of these structures is a key factor in terpene biosynthesis. Growth regulators can influence formation and development of essential oil biosynthesis and storage structures. The effect of plant hormone application on secretory structure formation was observed during a study of cytokinin's effect on Thimus mastichina essential oil production. In this work Fraternale and others (2003) verified higher yield of essential oil in the medium culture with benziladenine (BA) (10) at a concentration of $0.1 \mathrm{mg} \mathrm{L}^{-1}$. In leaves of $T$. mastichina plants treated with BA there was a larger density of glandular hair in post secretory stage. Although a direct correlation has not been demonstrated, the authors suggest an effect of BA on glandular hair development. In Norway spruce (Picea abies) jasmonate application altered plant anatomy raising the number of resiniferous ducts, and associated with its application a threefold increase in monoterpene concentrations like $\alpha$ - e $\beta$-pinene and limonene was observed (Erbilgin et al. 2006). In lavender (Lavandula dentata) a higher amount of leaves in plants cultured in vitro for 8 weeks with $0.1 \mathrm{mg} \mathrm{L}^{-1}(\mathrm{BA})$ was verified. The number of glands on the surface of leaves treated with BA was smaller, however they are not disrupted. In addition, the leaves showed an intense green color and remained young for a longer time. The observed effect was associated with leaf senescence delay and secretory gland differentiation, which keep them in the pre-secretory stage. Auxin (IBA) (11) was also used. Likewise to $\mathrm{BA}$, plants treated with IBA presented a small number of glands, but were disrupted (post secretory stage), indicating that auxin accelerated their differentiation (Sudriá et al. 2004).

The action associated with essential oil biosynthesis in various steps of metabolic pathways is also one of the manners through which growth regulators could affect essential oil production.

Methyl-jasmonate applications $(0.5 \mathrm{Mm})$ increased significantly the quantity of monoterpenes in basil (Ocimum basilicum). The content of terpenes in plants treated with methyl-jasmonate was higher than that found in control plants. The increase in eugenol and L-linalool compared to control plants was $56 \%$ and $43 \%$, respectively. The authors noted an increment in phenylpropanoid pathway products derived from phenylalanine ammonia-lyase (PAL), as well as an increase in the number of transcripts of the enzymes present in subsequent steps of the pathway, which explains the eugenol increase. The effect of methyl-jasmonate application on enzymes associated with monoterpenoid biosynthesis was not verified. This result indicates that exogenous applications of that hormone can influence the production of compounds present in basil essential oil by gene regulation, promoting an increase in the number of transcripts of the enzymes linked to metabolic pathway of those compounds (Kim et al. 2006; Li et al. 2007). Rodriguez-Saona et al. (2001) observed that cotton plants (Gossypium hirsutum L.) treated with MeJ emitted a great amount of inducible volatiles such as linalool and $\beta$-ocimene. According to the authors, this result indicates that MeJ activates enzymes associated with the biosynthesis of those compounds. Zhang et al. (2005) verified that after GA application (14 $\mu \mathrm{M})$ there was a $400 \%$ increase in the concentration of artemisinin compared to control plants. Treatment with $\mathrm{GA}_{3}$ does not correspond to an increase in amorpha-4,11-diene synthase, which catalyzes the first step in artemisinin biosynthesis. The authors suggest activation of artemisinic acid to artemisinin conversion as mechanism by which gibberellins increase artemisinin concentrations. Application of methyl-jasmonate $(50 \mu \mathrm{L})$ resulted in a rise of ten fold in emission of volatile compounds in Iva frutescens compared to control plants, producing an increase of 14,5 and 8-fold on $\alpha$-pinene, sabinene and limonene emission, respectively. According to the authors, the increase in volatile emissions treated with methyl-jasmonate could be a result of terpene syntase activation and de novo synthesis. Methyljasmonate activates a range of pathways in Iva frutescens like shykimate, octadenoid, mevalonate and methylerythritol-4 phosphate (Degenhardt and Lincoln 2006). In Chrysanthemum cinerariaefolium piretrin production increased 31 and $44 \%$ in relation to control for 50 and $100 \mathrm{mg} \mathrm{L}^{-1}$ ethrel concentrations, respectively. It was also observed that under ethrel treatment there was a higher incorporation of ${ }^{14} \mathrm{CO}_{2}$ in piretrins. According to the authors this result indicates that ethrel could influence the activity of enzymes linked to the piretrin biosynthetic pathway (Haque et al. 2007). In Catharanthus roseus cell suspension, Decendit et al. (1993) and Papon et al. (2005) observed an increase in geranyl 10-hidroxylase activity when the medium was supplied with cytokinin (zeatin). This enzyme acts in the terpene moiety of indolic alkaloids as ajmalicine, serpentine and catharantine. Oudin et al. (2007) verified that adding cytokinin to the medium increased the production of 
alkaloids with terpenic moiety. In in vitro culture of Lavandula dentata L. application of cytokinin ( $\left.0.1 \mathrm{mg} \mathrm{L}^{-1} \mathrm{BA}\right)$ had a positive effect on production and/or accumulation of essential oil. The increase was $150 \%$ related to control. Essential oil chemical composition was altered. The majority of compounds (1,8cineole, fenchole, camphor and borneol) were maintained, they represent $80 \%$ of total chemicals in essential oil. Nevertheless, cytokinin application increased camphor percentage and decreased 1,8-cineole, while other compounds didn't show alteration. Cytokinin treatment produced a $140 \%$ increase in HMG-CoA redutase activity, yet this was not directly linked to a rise in oil production, but is connected to whole plant metabolism, which demands a supply of products from the pathways where HMG-CoA redutase acts to primary metabolism. In relation to chemical composition alteration, an influence of growth regulator on enzyme activities could be the responsible factor (Sudriá et al. 1999). In Salvia officinalis and M. piperita plants, enzymes that participate in the synthesis of compounds present in essential oil were extracted after treatment with $10 \mathrm{ppm}$ of diphenylurea. It was observed that the activities of analyzed enzymes (bornyl pyrophosphate cyclase from $S$. officinalis and limonene cyclase from $M$. piperita) were higher in plants treated with hormone. Thus, the authors demonstrated that cytokinin foliar application stimulated essential oil accumulation, at least due to the direct effect on metabolism of monoterpenoids (El-Keltawi and Croteau 1987).

Concentration and source of the growth regulators applied are factors that can result in different responses.

El-Keltawi and Croteau (1987) applied different cytokinin sources (cinetin, diphenylurea (12), benzylaminopurine (13) and zeatin (14)) on concentrations from 1 to $10 \mathrm{ppm}$ in species of Lamiaceae (Mentha piperita, M. spicata, M. suaveolens, Salvia officinalis e Lavandula vera), and verified that cinetin and diphenylurea were the most effective in increasing essential oil production. Although alterations on oxygenated monoterpenes have been detected, cytokinins did not drastically change essential oil composition of the studied species. There was reduction in content of some chemicals, nevertheless the absolute levels increased. According to the authors, the primary effect of cytokinins was a stimulus of monoterpene accumulation. The cinetin and diphenylurea effects were higher than that attributed to the effects related to growth and developmental changes, or on gland formation and density, thus an effect on metabolism was suggested.

In a study about the effects of different cytokinin sources like benzylaminopurine, cinetin and N6-isopenteniladenine on monoterpene biosynthesis in Cymbopogon species, Craveiro et al. (1989) verified an increase of 9 and $93 \%$ on the content of essential oil in $C$. citratus when treated with benzylaminopurine and N6-isopenteniladenine, respectively. Otherwise cinetin decreased essential oil content by $19 \%$.

Just as different species can present variable responses to plant hormone application, one species could respond in different ways according to its development stage and number or interval of applications.

Exogenous application of cytokinin (BAP - $50 \mathrm{mg} \mathrm{L}^{-1}$ ) on Mentha piperita L., at 15 and 30 days after the beginning of the experiment, and with harvest at 45 days resulted in an increase of plant dry mass. The time of application didn't influence oil yield, but changed its chemical composition (Scravoni et al. 2006).

Application of cinetin in Rosa damascena demonstrated that the concentration of $5 \mathrm{mg} \mathrm{L}^{-1}$ raises citronellal and geranyl acetate production by $8 \%$ in the first year of application and $20 \%$ in the second year Faroogi et al. (1993). Using the same source at the concentration of $20 \mathrm{mg} \mathrm{L}^{-1}$, the increase was 13 and $24 \%$, in the first and second year, respectively.

Figueiredo et al. (2006) analyzed the effect of application of hormones such as gibberellins and analogues of plant hormones like ethrel in Cymbopogon citratus at different times in a year and did not verify the effect of hormones on essential oil production.

Not only quantity, but also quality of essential oil can be influenced by growth regulator application.

Arikat et al. (2004), comparing production and chemical composition of sage (Salvia fruticosa Mill.) essential oil, observed that plants grown in vitro showed a high content of essential oil $(0.7 \%)$ when compared to plants grown in a greenhouse $(0.34 \%)$. They also verified that the main compounds ( $\alpha$-pinene, 1,8-cineole, camphor and borneol) were the same under both conditions. However, the percentages of camphor and borneol were expressively higher in plants grown in vitro. The authors report that essential oil percentages in plants grown in vitro are often higher to those 
found in plants from a greenhouse, associating this result with the presence of growth regulators, especially cytokinins.

In Salvia officinalis $L$. the chemical composition changed with gibberellic acid $\left(100 \mathrm{mg} \mathrm{L}^{-1}\right)$ application, with a significant reduction of $\beta$-tujone and $\alpha$-humulene in relation to the control plants (Povh and Ono 2007).

Stoeva and lliev (1997) applying citokinins (4PU-30 (15) -25 and $50 \mathrm{mg} \mathrm{L}^{-1}$; DROPP (16)- 50 and $\left.100 \mathrm{mg} \mathrm{L}^{-1}\right)$ in mint (Mentha spicata (L.) Huds. Cv. CS-87) verified changes in the chemical composition of essential oil, where 1,8-cineole presented an increase and carvone was reduced.
In Melissa officinalis grown in culture medium for 60 days with auxin and cytokinin complement (IAA $11.42 \mu \mathrm{mol} \mathrm{L}^{-1}$; BA $8.87 \mu \mathrm{mol} \mathrm{L}^{-1}$ and IAA+BA), an increase of 1.4 fold on nerol and 4.1 fold on geraniol was verified. Plants grown on control medium and ex vitro, however, presented higher percentages of neral and geranial. According to the authors, the hormones added to culture medium could have inhibited reactions of reduction from alcohol to aldehydes (Silva et al. 2005).

Table 1 summarizes the findings of this review, i.e., the effects of applications of various growth regulators on different points of plant growth, development and metabolism.<smiles></smiles>

7<smiles>O=C(O)Cc1cccc2ccccc12</smiles>

8<smiles>O=P(O)(O)CCCl</smiles>

9<smiles>Nc1ncn(Cc2ccccc2)c2ncnc1-2</smiles><smiles>O=C(O)CCCc1c[nH]c2ccccc12</smiles><smiles>O=C(Nc1ccccc1)Nc1ccccc1</smiles>

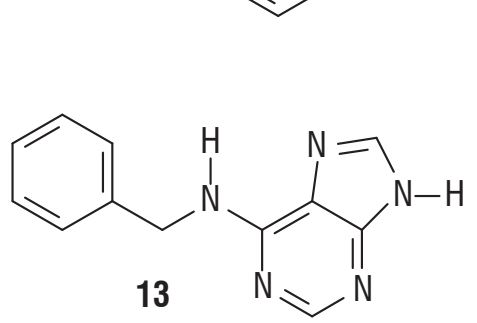<smiles>O=C(Nc1ccccc1)Nc1ccnc(Cl)c1</smiles>

15<smiles>C/C(=C\CNc1ncnc2[nH]cnc12)CO</smiles>

14

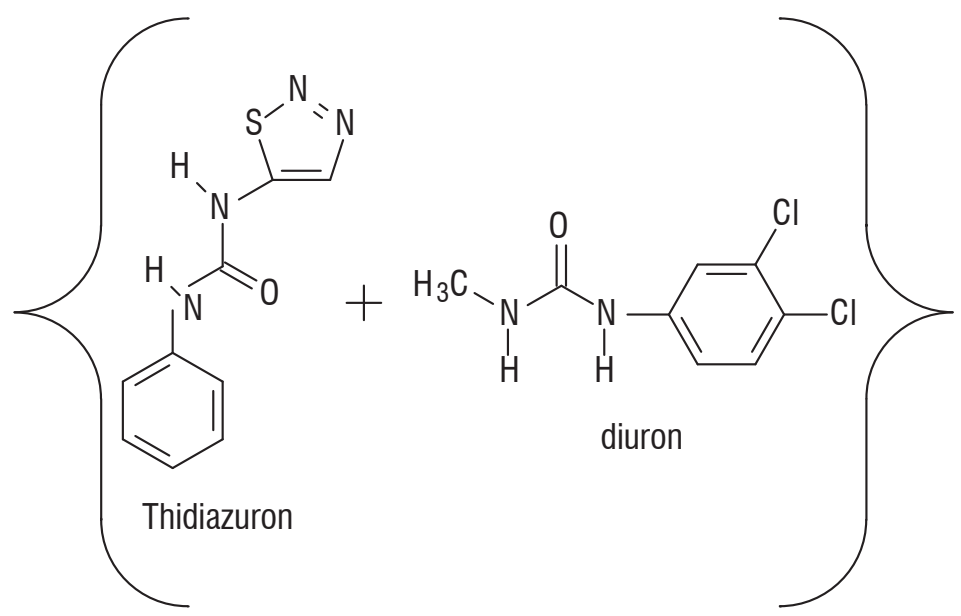

16

Figure 4. Structures of some growth regulators cited in this review. 
Table 1: Effects of growth regulators and/or its synthetic analogues on essential oil production. Legend: significative effect (x); no effect (ns); production rising (+); decrease of production (-); effect not informed $(\varnothing)$; not mentioned (--).

\begin{tabular}{|c|c|c|c|c|c|}
\hline \multirow{2}{*}{ Specie } & \multirow{2}{*}{$\begin{array}{l}\text { Growth } \\
\text { regulator }\end{array}$} & \multicolumn{2}{|c|}{ Observed effect } & \multirow{2}{*}{ Related factor } & \multirow{2}{*}{ Reference } \\
\hline & & Quantitative & Qualitative & & \\
\hline Artemisia annua & GA & $\varnothing$ & $x$ & Activation of compounds conversion & Zhang et al. 2005 \\
\hline Catharanthus roseus & CYT & + & $x$ & Increase of enzyme activity & $\begin{array}{c}\text { Decendit et al. 1993; Papon et al. 2005; } \\
\text { Oudin et al. } 2007\end{array}$ \\
\hline $\begin{array}{l}\text { Chrysanthemum } \\
\text { cinerariaefolium }\end{array}$ & ET & $\varnothing$ & $x$ & Enzyme activation & Haque et al. 2007 \\
\hline Cymbopogon citratus & CYT & + & $\varnothing$ & Source of hormone & Craveiro et al. 1989 \\
\hline C. citratus & $\mathrm{GA}$ & ns & $\varnothing$ & -------- & Figueiredo et al. 2006 \\
\hline Gossypium hirsutum & JA & + & $x$ & Enzyme activation & Rodriguez-Saona et al. 2001 \\
\hline Iva frutescens & JA & $\varnothing$ & $x$ & $\begin{array}{c}\text { Activation of terpene syntase and de novo } \\
\text { synthesis }\end{array}$ & Degenhardt and Lincoln 2006 \\
\hline L. dentata & CYT & + & $\varnothing$ & $\begin{array}{c}\text { High production of leaves, secretory structure } \\
\text { development }\end{array}$ & Sudriá et al. 2004 \\
\hline L. dentata & AUX & - & $\varnothing$ & Secretory structures development & Sudriá et al. 2004 \\
\hline L. dentata & CYT & + & $x$ & Increase of enzyme activity & Sudriá et al. 1999 \\
\hline Lavandula vera & CYT & + & $\varnothing$ & Acting on monoterpene metabolism & El-Keltawi and Croteau 1987 \\
\hline Mentha arvensis & CYT & + & $\varnothing$ & Biomass increment & Farooqi et al. 2003 \\
\hline $\begin{array}{l}\text { M. arvensis var. } \\
\text { piperascens }\end{array}$ & CYT & + & $\varnothing$ & High production of leaves & Faroogi and Sharma 1988 \\
\hline $\begin{array}{l}\text { M. arvensis var. } \\
\text { piperascens }\end{array}$ & AUX & + & $\varnothing$ & High production of leaves & Faroogi and Sharma 1988 \\
\hline M. piperita & CYT & + & $x$ & Increase of enzyme activity & El-Keltawi and Croteau 1987 \\
\hline M. spicata & CYT & + & $\varnothing$ & Acting on monoterpene metabolism & El-Keltawi and Croteau 1987 \\
\hline M. suaveolens & CYT & + & $\varnothing$ & Acting on monoterpene metabolism & El-Keltawi and Croteau 1987 \\
\hline M. piperita & CYT & ns & $x$ & Application period & Scravoni et al. 2006 \\
\hline M. spicata & CYT & $\varnothing$ & $x$ & -------- & Stoeva and lliev 1997 \\
\hline Melissa officinalis & CYT & $\varnothing$ & $x$ & Acting on chemical reactions & Silva et al. 2005 \\
\hline Ocimum basilicum & $J A$ & + & $x$ & Increase of enzyme transcripts & Kim et al. 2006; Li et al. 2007 \\
\hline Picea abies & $J A$ & + & $x$ & High number of secretory structure & Erbilgin et al. 2006 \\
\hline Rosa damascena & CYT & $\varnothing$ & $x$ & $\begin{array}{l}\text { Application period and hormone } \\
\text { concentration }\end{array}$ & Farooqi et al. 1993 \\
\hline S. officinalis & GA & + & $x$ & High production of leaves & Poyh and Ono 2006 \\
\hline S. officinalis & CYT & + & $x$ & Increase of enzyme activity & El-Keltawi and Croteau 1987 \\
\hline Salvia fruticosa & CYT & + & $x$ & Presence of hormone & Arikat and others 2004 \\
\hline Thimus mastichina & CYT & + & $\varnothing$ & Secretory structures development & Fraternale et al. 2003 \\
\hline
\end{tabular}

Acknowledgments: UENF, FAPERJ and CAPES for financial support 


\section{REFERENCES}

Abrahim D, Francischini AC, Pergo EM, Kelmer-Bracht AM, Ishii-Iwamoto $E$ (2003) Effects of $\alpha$-pinene on the mitochondrial respiration of maize seedlings. Plant Physiol and Biochem 41: 985-991.

Arikat NA, Jawad FM, Karam NS.; Shibli RA (2004) Micropropagation and accumulation of essential oils in wild sage (Sa/via fruticosa Mill.). Sci Hortic 100: 193-202.

Basra AS (2000) Plant growth regulators in agriculture and horticulture: their role and commercial uses. Harworth Press, Philadelphia. $264 \mathrm{p}$.

Bohlmann J, Keeling Cl (2008) Terpenoid biomaterials. Plant J 54: 656-669.

Chernyad 'Ev II (2000) Ontogenetic changes in the photosynthetic apparatus and effects of cytokinins - Review. Appl Biochem Micro 36 (6): 527-539.

Bohlmann J, Meyer-Gauen G, Croteau R (1998) Plant terpenoid synthases: molecular biology and phylogenetic analysis. PNAS 95: 4126-4133.

Burfield T, Reekie SL (2005) Mosquitoes, malaria and essential oils. Intern J Aromather 15: 30-41.

Clouse SD, Sasse JM (1998) Brassinosteroids: essential regulators of plant growth and development. Annu Rev Plant Physiol Mol Biol 49: 427-451.

Craveiro A, Barreira ES, Rabi J, Dagnino D (1989) Estudo sobre o efeito de citocininas na biossíntese de monoterpenos. In: SBPC, 1989, Fortaleza-CE. P. 531.

Dewick PM (2009) Medicinal natural products: a biosynthetic approach. $3^{\text {rd }}$ edition. Wiley, England 550p.

Erbelgin N, Krokene P, Christiansen E, Gazmend Z, Gershenzon J (2006) Exogenous application of methyl jasmonate elicits defenses in Norway spruce (Picea abies) and reduces host colonization by the bark beetle IpS typographus. Oecologia 148: 426-436.

Decendit A, Petit G, Andreu F, Doireau P, Mérillon JM, Rideau M (1993) Putative sites of cytokinin action during their enhancing effect on indole alkaloid accumulation in periwinkle cell suspensions. Plant Cell Rep 12: 710-712.

Degenhardt DC, Lincoln DE (2006) Volatile emissions from an odorous plant in response to herbivory and methyl jasmonate exposure. J Chem Ecol 32: 725-743.

El-Keltawi NE, Croteau R (1987) Influence of foliar applied cytokinins on growth and essential oil content of several members of the lamiaceae. Phytochemistry 26(4): 891-895.

El Tamer MK (2002) Molecular regulation of plant monoterpene biosynthesis in relation to fragrance. Wageningen University: http://library.wur.nl/wda/ dissertations/dis3314

Faroogi AHA, Khan A, Sharma S (2003) Effect of kinetin and chlormequat chloride on growth, leaf abscission and essential oil yield in Mentha arvensis. Indian Perfumer 47(4): 359-363.

Farooqi AH, Sharma S (1988) Effect of growth retardants on growth and essential oil content in Japanese mint. Plant Growth Regul 7: 39-45.

Faroogi AHA, Sharma S, Naqvi AA, Khan A (1993) The effect of kinetin on flower and oil production in Rosa damascena. J Essent Oil Res 5: 305-309.

Faroogi AHA, Shukla A (1990) Utilization of plant growth regulators in aromatic plant production. Chromatography 12: 152-157.

Figueiredo R0, Delachiave MEA, Ming LC (2006) Reguladores vegetais na produção de biomassa e teor de óleos essenciais em Cymbopogon citratus (DC.) Stapf, em diferentes épocas do ano. Rev Bras PI Med 8(3): 31-35.

Fraternali D, Giamperi L, Ricci D, Rocchi MBL, Guidi L, Epifano F, Marcotullio FC (2003) The effect of triacontanol on micropropagation and on secretory system of Thymus mastichina. Plant Cell Tissue Organ Cult 74: 87-97.

Gershenzon J (1994) Metabolic costs of terpenoid accumulation in higher plants. J Chem Ecol 20(6): 1281-1328.

Gobbo-Neto L, Lopes NP (2007) Plantas medicinais: fatores de influência no conteúdo de metabólitos secundários. Quim Nova 30(2): 374-381.
Gottlieb OR, Salatino A (1987) Função e evolução de óleos essenciais e de suas estruturas secretoras. Ciênc Cult 39(8): 707-716.

Gray WM (2004) Hormonal regulation of plant growth and development. PLoS Biol 2(9): 1270-1273.

Hadacek F (2002) Secondary metabolites as plant traits: current assessment and future perspectives. Crit Rev Plant Sci 21(4): 273-322.

Haque S, Farooqi AHA, Gupta MM, Sangwan RS, Khan A (2007) Effect of ethrel, chlormequat chloride and pachlobutrazol on growth and pyrethrins accumulation in Chrysanthemum cinerariaefolium Vis. Plant Growth Regul 51: 263-269.

Hirose N, Takei K, Kuroha T, Kamada-Nobusada T, Hayashi H, Sakakibara H (2007) Regulation of cytokinin biosynthesis, compartmentalization, and translocation. J Exp Bot 14: 1-9.

Kesselmeier J, Staudt M (1999) Biogenic volatile organic compounds (VOC): an overview of emission. physiology and ecology. J Atmos Chem 33: 23-88.

Kieber JJ (2001) Cytokinin. In: The Arabidopsis Book. Somerville, C. Meyerowitz, E. (eds): American Society of Plant Biologists. Doi/10.1199/tab. 0063, http://www.aspb.org/publications/arabidopsis/

Kim H-J, Chen F, Chen F, Rajapakse NC (2006) Effect of methyl jasmonate on secondary metabolites of sweet basil (Ocimum basilicum L.). J Agric Food Chem 54: 2327-2332.

Li Z, Wang X, Chen F, Kim H-J (2007) Chemical changes and over expressed genes in sweet basil (Ocimum basilicum L.) upon methyl jasmonate treatment. J Agri. Food Chem 55: 706-713.

Lima HRP, Kaplan MAC, Cruz AVM (2003) Influência dos fatores abióticos na produção e variabilidade de terpenóides em plantas. Floresta ambient 10(2): 71-77.

Mahmoud SS, Croteau RB (2002) Strategies for transgenic manipulation of monoterpene biosynthesis in plants - Review. Trends Plant Sci 7(8):366373.

Maia NB, Bovi OA, Zullo MAT, Perecin MB, Granja NP, Carmello QAC, Robaina C, Coll F (2004) Hydroponic cultivation of Mint and vetiver with spirostane analogues of brassinosteroids. Acta Hort 664: 55-59.

Nambara E, Marion-Poll A (2005) Abscisic acid biosynthesis and catabolism. Annu Rev Plant Biol 56: 165-185.

Ortuño A, Oncina R, Botia JM, Del Rio JA (1999) Regulation of diosgenin expression in Trigonella foenum-graeco plants by different plant growth regulators. Food Chem 65: 227-232.

Oudin A, Mahroug S, Courdavault V, Hervouet N, Zelwer C, RodríguezConcepción M, St-Pierre B, Burlat V (2007) Spatial distribution and hormonal regulation of gene products from methyl erythritol phosphate and monoterpene-secoiridoid pathways in Catharanthus roseus. Plant Mol Biol 65:13-30.

Papon N, Bremer J, Vansiri A, Andreu F, Rideau M, Crèche J (2005) Cytokinin and ethylene control indole alkaloid production at the level of the MEP/ terpenoid pathway in Catharanthus roseus suspension cells. Planta Med 71: 572-574.

Paré PW, Tumlinson JH (1999) Plant volatiles as a defense against insect herbivores. Plant Physiol 121: 325-331.

Povh JA, Ono EO (2006) Rendimento do óleo essencial de Salvia officinalis L. sob ação de reguladores vegetais. Acta Sci Biol Sci 28(3): 189-193.

Povh JÁ, Ono EO (2007) Efeito do ácido giberélico na composição do óleo essencial de Salvia officinalis L. Publ UEPG Biol Health Sci 13(1/2): 7-10.

Pozo JC, Lopez-Matas MA, Ramirez-Parra E, Gutierrez C (2005) Hormonal control of the plant cell cycle. Physiol Plant 123: 173-183.

Rodriguez-Concepción M, Boronato A (2002) Elucidation of the methylerytritol phosphate pathway for isoprenoid biosynthesis in bacteria and plastids. A metabolic milestone achieved through genomics. Plant Physiol 130: 10791089. 
Rodriguez-Saona C, Crafts-Brandner SJ, Paré PW, Henneberry TJ (2001) Exogenous methyl jasmonate induces volate emissions in cotton plants. $\mathrm{J}$ Chem Ecol 27(4): 679-695.

Sangwan NS, Faroogi AHA, Shabih F, Sangwan RS (2001) Regulation of essential oil production in plants. Plant Growth Regul 34: 03-21.

Schaller F, Schaller A, Stintzi A (2005) Biosynthesis and metabolism of jasmonates. J. Plant Growth Regul 23: 179-199.

Schwab W, Davidovich-Rikanati R, Lewisohn E (2008) Biosynthesis of plantderived flavor compounds. Plant J 54: 712-732.

Scravoni J, Vasconcellos MC, Valmorbida J, Ferri AF, Marques MOM, Ono EO, Rodrigues JD (2006) Rendimento e composição química do óleo essencial de Mentha piperita L. submetida a aplicações de giberelina e citocinina. Rev Bras PI Med 8(4): 40-43.

Silva AS (2002) Análise técnica econômica e de tendências da indústria brasileira de óleos essenciais. Papel Virtual, Rio de Janeiro. 202 p.

Silva S, Sato A, Lage CLS, Gil RASS, Azevedo DA, Esquibel MA (2005) Essential oil composition of Melissa officinalis L. in vitro produced under the influence of growth regulators. J Braz Chem Soc 16(6B): 1387-1390.

Spatz AK, Gray WM (2008) Plant Hormone Receptors: new perceptions. Gene Dev 22: 2139-2148.

Stoeva T, lliev L (1997) Influence of some phenylureia cytokinins on spearmint essential oil composition. Bulg J Plant Physiol 23(3-4): 66-71.
Sudriá C, Piñol MT, Palazón J, Cusidó RM, Vila R, Morales C, Bonfill M, Cañigueral S (1999) Influence of plant growth regulators on the growth and essential oil content of cultured Lavandula dentata plantlets. Plant Cell Tissue Organ Cult 58: 177-184.

Sudriá C, Palazón J, Cusidó R, Bonfill M, Piñol MT, Morales C (2004) Effect of benzyladenine and indolebutyric acid on ultrastructure, glands formation, and essential oil accumulation in Lavandula dentata plantlets. Physiol Plant 44(1): 1-6.

Taiz L, Zeiger E (2004) Fisiologia Vegetal. $3^{\mathrm{a}}$ ed. Artmed, Porto Alegre. $719 \mathrm{p}$.

Teale, WD.; Papanov, IA.; Palme, K. (2006) Auxin in action: signaling, transport and the control of plant growth and development. Nat Rev Mol Cell Biol 7: 847-859.

Trapp SC, Croteau RB (2001) Genomic organization of plant terpene synthases and molecular evolutionary implications. Genetics 158: 811-832.

Wasternack C (2007) Jasmonates: an update on biosynthesis, signal transduction and action in plant stress response, growth and development. Ann Bot 100(4): 681-697.

Weathers PJ, Bunk G, Mccoy MC (2005) The effect of phytohormones on growth and artemisinin production in Artemisia annua hairy roots. In Vitro Cell Dev - PI 41: 47-53.

Zhang YS, Ye HC, Liu BY, Wang H, Li GF (2005) Exogenous $\mathrm{GA}_{3}$ an flowering induce the conversion of artemisinic acid to artemisinin in Artemisia annua plants. Russian J Plant Physiol 52(1): 68-73. 